\title{
Educational Values in Minangkabau Opera Malin Nan Kondang
}

\author{
Iswandi $^{1, *}$, Edi Suisno ${ }^{1}$ RM Pramutomo ${ }^{2}$ Lili Suparli $^{3}$ Novesar Jamarun $^{1}$
}

\author{
${ }^{l}$ Institut Seni Indonesia Padangpanjang, Padangpanjang, Indonesia \\ ${ }^{2}$ Institut Seni Indonesia Surakarta, Surakarta, Indonesia \\ ${ }^{3}$ Institut Seni Budaya Indonesia Bandung, Bandung, Indonesia \\ *Corresponding author. Email: iwandi014@gmail.com
}

\begin{abstract}
Malin Nan Kondang as Minangkabau Opera is a performance art that antithesis of Kaba Malin Kundang. Many people interpreted Malin Nan Kondang folklore as a son who was successful overseas but disobedient to his mother. Minangkabau Opera Malin Nan Kondang tells about Minangkabau man who has a perseverance nature, polite to his parents and wants to make his mother happy with his wealthy. His success abroad does not make him arrogant, even though he has a lover, but to fight his love, he always shows polite character to his mother. This research is qualitative research using descriptive methods that highlight the depth of appreciation of the interaction between players seen in the show and the text/script. The researcher described the data on educational values in text/script and the Minangkabau Opera Malin Nan Kondang performance. Main data of this study are texts/manuscripts and performances of Malin Nan Kondang Minangkabau Opera. It has several educational values, including: (1) the value of truth, (2) the value of persistence and perseverance, (3) the value of ethics, (4) the value of togetherness, and (5) the aesthetic value.
\end{abstract}

Keywords: Opera, script, Malin Nan Kondang, educational values

\section{INTRODUCTION}

West Sumatra is known to have a wealth of Minangkabau cultural arts. One of the wealth of these cultural arts is the existence of folklore, which in Minangkabau literature is manifested in the form of kaba. $K a b a$ is a rhythmic prose art that contains a story (narrative) and classified as a long story. As rhythmic prose, expressions of kaba utterance are conveyed by singing [1]. One of the most popular kaba in Minangkabau literature is Malin Kundang. Malin Kundang folklore tells the story of a successful young man overseas, who later becomes disobedient to his parents (mother). This story seems to have become a very influential moral creed not only in Minangkabau but also in other parts of Nusantara.

Malin Kundang folklore is not only an inspiration for storytelling, but also a starting point in creating new works, both in the form of other literary genres, as well as in the form of works of art as a result of transformation or ecranisation. Minangkabau Opera Malin Nan Kondang as a new form of art is a work of art inspired by Malin Kundang folklore. The Malin Nan Kondang Opera created as a form of transfer from the disobedient of a young man to his mother to become a young man who has a hard working character, tough personality, and respect for his parents. Minangkabau Opera Malin Nan Kondang creates as an effort to change the judgment of many people on the label given to
Minangkabau youth who were identical to the child who disobeyed the mother who gave birth to him.

The Minangkabau Opera Malin Nan Kondang is an effort to manifest the transformation of design as a work of art consisting of theater, dance, and music. These three fields of art are packaged into the whole unit without anything being highlighted the most, instead become one force that is inseparable from one another. The Minangkabau Opera Malin Nan Kondang consists of eight scenes.

The Minangkabau Opera Malin Nan Kondang as a form of transfer from Malin Kundang folklore contains many values such as cultural values, educational values, and so on. Values are often associated with culture, Koentjaraningrat [2] argues that cultural values consist of conceptions that live in the minds of most members of society regarding things they consider noble. Furthermore, Robert Sibarani [3] states that cultural values and norms are the conceptions that exist in the minds of most communities about the culture they perceive as good and bad. Cultural values and norms are not personal conceptions but conceptions of community members; there is a shared community system to determine values and norms in a tradition.

These values are very interesting to be studied in-depth to find out the strength of a work of art as well as science development. In connection with these values, the author will discuss the educational values contained in the 
Opera Malin Nan Kondang. It is hoped that the discussion of educational values will give an idea that Opera Malin Nan Kondang has strength from both textual and contextual aspects. This will offer an overview of the significant difference between the Minangkabau Opera Malin Nan Kondang and the Malin Kundang folklore.

Value is something good and valuable. In simple terms, values are a valuable reference for beliefs to make choices about how to act in life [4]. Values include abstract conceptions considered as good and bad. The value is an abstract that needs several indicators so everyone can understand the conception generally. Values include abstract conceptions considered as good and bad. The value is an abstract that needs several indicators so everyone can understand the conception generally. Several indicators of value are; (1) the nature of life concept, (2) the nature of human work concept, (3) the nature of time concept, (4) the environment and nature concept, and (5) nature social environment concept. Based on the explanation above Samovar and Potter [5] state, values are the ideas that underlie the cultural patterns of society in responding to physical and spiritual elements. Values are abstract conceptions, ideas, which are very important in nature used as references, benchmarks, guidelines, and reference for beliefs in performing deeds and actions. Values distinguish as good and bad in human life and become the basis for the cultural patterns of a society. Furthermore Koentjaraningrat [6] states that the term value is equal to mentality. The mentality is the whole of the contents and abilities of the human mind and soul realm in responding to their environment.

Education is the process of forming thoughts, building behavior, and attitudes, glorifying human humanity towards maturity and expected behavior under human dignity. Soekidjo Notoatmodjo [7] defines in general "Education is an effort that is planned to influence other people, be it individuals, groups, or society so that they do what actors of education expect". Furthermore, according to Nursid [8] education is the process of changing individual behavior towards maturity. The values that must exist in education according to Sjarkawi [9] are; (1) good deeds, (2) trustworthiness, (3) anticipation, (4) prejudice, (5) working hard, (6) being civilized, (7) dare to do the right thing, (8) dare to take risks, (9) be disciplined, (10) broad-hearted, (11) soft-hearted, (12) have faith and piety, (13) take initiative, (14) have a strong will, (15) have personality, (16) think ahead, (17) are modest, (18) passionate, (19) are constructive, (20) are responsible, and have similar values. Furthermore, Bahadur [10] educational values in the randai text include religious values, toughtness education values, caring education values, and honesty values.

For the purposes of research, the values of education summarized into four values, namely: (1) the value of religious education with indicators of attitude and behavior of believing in God the Almighty, obeying God's commands, staying away from God's prohibitions, being grateful, trusting, and sincere. (2) The value of toughness education with indicators of attitude and behavior of discipline, resilience, and courage to take risks. (3) The values of caring education with indicators of attitude and behavior of affection, courtesy, forgiveness, friendship/ communicative, social care, and family love. (4) The values of honesty education with indicators of responsible attitudes and behavior, fulfilling obligations, gracefulness, keeping promises, and being democratic [11].

\section{METHOD}

This research used qualitative research using descriptive methods. Semi [12] argues that descriptive qualitative research is research that prioritizes the depth of appreciation of the interaction between concepts that are being studied empirically or conducted without using numbers. The researcher described the educational values contained in the text/script and the Minangkabau Opera Malin Nan Kondang performance. The texts/manuscripts and performances of Malin Nan Kondang Minangkabau Opera were used as the main data sources in this study. Ratna [13] states that research using content review techniques emphasizes how to interpret content and symbolic interactions that occur in communication events. There are two kinds of content study techniques, namely latent content and communication content. Latent content is the content contained in documents and manuscripts, while communication content is the message contained as a result of the communication that occurs. Content analysis techniques in literary works can be in the form of efforts to understand literary works which include extrinsic elements such as moral messages, educational values, cultural values, and so on. The content analysis in this study is intended to reveal the meaning contained in the script and the performance of the Minangkabau Malin Nan Kondang Opera. The data inventory format that the author used as data inventory is related to data about educational values in the script/text and the Minangkabau Opera performance of Malin Nan Kondang. The research data were analyzed through four stages, namely identification, classification, interpretation, and reporting.

\section{RESULTS AND DISCUSSION}

\subsection{Structure of Minangkabau Opera Malin Nan Kondang}

Minangkabau Opera Malin Nan Kondang is a new work of art as a form of transfer from the Malin Kundang folklore, which is designed in an opera performance by referring to the principles of musical drama. Opera performance is a type of theater performance that initially only recognized dialogue in the form of singing. The characters convey all utterances by singing a song, the lyrics which contain the impressions and desires of the characters towards other characters. Along with the development, the term 'opera' finally expanded its meaning. Opera is often used as a theater label, which in its appearance emphasizes musical and singing aspects. Performances that present several scenes of characters by telling stories through the chanting of songs are commonly called Opera, such as, Primadona 
Opera (Koma Theater), Bom Waktu Opera (Koma Theater), Sangkuriang Opera (ISBI Bandung), and so on.

Observing the various forms of current opera, Malin Nan Kondang Minangkabau Opera has a characteristic that the power of dialogue is presented as a 'binding' for the creation of scene by scene. The structure of Malin Nan Kondang Minangkabau Opera consists of eight scenes as follows.

The first scene depicts Malin's relationship with Nilam which is getting closer as evidenced by Malin's promise and commitment to keep wanting Nilam as his wife after his return from his planned overseas trip. In the first scene, between two characters dialogues are displayed in poetic words, while the space that becomes the background of the event is symbolically generated. In addition to using selected words, the dialogue between these characters also uses songs that are reciprocated by singing as well.

The second scene is a dialogue between Malin and Mandeh (Malin's mother). Malin said goodbye to go wander to his mother. In this scene, Malin emphasizes his determination to change his life which is still plagued by poverty. Even Malin's mother, hardly let Malin's leave because she believed in the glory of Malin's determination. In this second scene, the two characters dialogue show realistically by using the selected daily language and using the selected words.

The third scene depicts the separation between Mandeh and Malin. A series of character movements are arranged to emphasize the 'sadness' of the separation that occurred. The scene begins with a verbal dialogue that cores Mandeh's messages to Malin, which becomes guidance for Malin while overseas. The verbal dialogue ended with a chant by Mandeh. The scene in this section ends with Malin's leave, which is arranged in two divisions of motion, describing Malin's hesitation in having to leave Mandeh. The dialogue in this section is replaced with a verbal dialogue containing important creeds which should be used as guidance for Malin in interpreting the word 'rantau' for a Minangkabau man.

The fourth scene depicts a target setting, which is an arena devoted to practicing pencak silat. In this target, Malin was saying goodbye to Datuk, as the leader of a clan or tribe. In the scene, verbal dialogue is told through various silat movements. Every single sentence in the dialogue is created with a silat movement motive, either by changing the stance, blocking movements, punching movements, or movements to locking the opponent's movements. Dialogue is formatted with emphasis on diction (laxis) and is dynamic considering that each word contains noble messages that migrants must guide so they do not lose their principles of life while overseas. This scene ends with a series of tapuak galembong movements to affirm the soul of the warrior and the firmness of faith.

The fifth scene depicts the psychological situation of the long-distance relationship between Malin and Nilam. The mental condition that experiences 'turmoil' is presented in the form of Out of Sound (OS), which is dialogue delivery without presenting the characters on the stage. The presence of the figures (Malin and Nilam) is symbolized in the form of a dance performed by a male and a female dancer. The movements carried out by the two dancers have a stronger intensity and are increasingly in tempo. The playing area for the two dancers will be limited through the use of a focus lamp and switched on alternately according to the dialogue brought by Malin and Nilam character. The dialogue that is played is in the form of poetry which is divided into four verses of poetry, which are played alternately.

The sixth scene depicts the complications of Nilam's problems, namely when she faces the terror of Datuk Kayo, a man who forces propose her. This scene begins with an argument between Nilam and Datuk Kayo. The composition of actors' movement and blocking in this event were arranged realistically by referring to the motive for the action. After Datuk Kayo's leave, which was marked by the decline of Nilam in deep sadness, the affirmation of the atmosphere was manifested in dance movements that used cloth. The dance begins with a simultaneous movement between Nilam and the dancers. After the simultaneous dance was followed by a single dance movement (solo) as a symbol of Nilam's feeling, which was deeply injured by Datuk Kayo's terror.

The seventh scene is episodic of Malin's return from overseas. This scene is divided into several beats (grouping dialogues under the scene), namely: the beat of the meeting between Malin and Nilam, the beat of Mandeh's presence that wants Malin to stay away from Nilam, and the beat of Datuk who advises Mandeh to support the love relationship between Malin and Nilam. The whole beat scene design is arranged with a realistic acting approach. Dialogue is spoken by giving an approach to the need for emotional changes in character. The movements of the actors are based on action motives. Everything is packaged in daily practice, except for the beat meeting between Datuk and Mandeh which is designed with a dance movement configuration. The dance is designed to create a dynamic affirmation in the plot or storyline.

Scene eight represents the turning point of Mandeh's character. This scene is divided into two beats, namely the beat of Malin's efforts in convincing Nilam that his love is unchanging and the beat of Mandeh's change of attitude which finally blesses the relationship between Malin and Nilam. This scene uses verbal dialogue and a chant sung by Mandeh. In this scene, there are several elements which include: setting design, designing costume and make-up, designing lights, and designing properties. The scene ends with the gathering of all the characters to hold Malin's and Nilam's wedding party.

\subsection{Educational Values in Malin Nan Kondang Minangkabau Opera}

The value of education is something that is believed to be true and encourages people to act positively in their own life or in society. The educational value in the artwork referred to the value that aims to educate a person or individual to become a good human being in the sense of education. The value of education in literary works is 
divided into four types, namely: moral values, truth values, beauty values, and religious values. Malin Nan Kondang Minangkabau Opera is a form of performance art in which there is theater art that uses text or scripts. In this regard, the text/script and its performances certainly have educational values that contain cultural values, ethical values, and aesthetic values.

\subsubsection{Truth Value}

Minangkabau Opera Malin Nan Kondang text/script illustrates that it has a truth value that is seen in the scene of Datuk and Malin (scene 4). Datuk as the brother of Malin's mother (Mandeh) advised Malin who would fight for his life overseas. As Minangkabau community, Datuk gave advice starting with a question about the determination of Malin who was going to wander. The advice is given by Datuk while asking questions about how to earn a living and use assets with Islamic concepts. Datuk wants Malin to live in the demands of Islam. Datuk provides education as a guide for Malin to navigate life both in this world and in the afterlife.

These educational seen in the pieces of the text, "what do you use your property for, but also where do you get your property, your position". The sentence in this piece of the manuscript illustrates that in the concept of Islam, humans in lawfully seeking sustenance need, there are guidelines in the $\mathrm{Al}$ Quran that Muslims must obey. Likewise, after sustenance in the form of assets that have been obtained, where it will be used. In this context, Datuk (Mamak) performs his obligation morally to provide advice to his nephews when nephews enter adulthood, including when they are leaving. The manuscript about the conversation between Datuk and Malin was followed by Malin's statement which said that based on the questions and advice given by the Datuk, Malin replied, "I will try to go on a straight path". Datuk tried to test Malin's statement by said "can you show me what a turning road looks like", Malin said, "If we justify what God has forbidden, Datuk, for example stealing, seizing other people's property". This dialogue illustrates that in Minangkabau, Datuk (Mamak) has a very noble function, which is to provide guidance and advice to nephews to have a good life experience, namely he must see what is halal and haram.

\subsubsection{The Value of Persistence and Perseverance}

The value of persistence and perseverance of Malin's heart is conveyed to his mother (Mandeh). Malin has a strong spirit to uplift the dignity of himself and his family that has a simple life, by the intention of wander. The image of persistence in the conversation between Malin and his mother (scene 2) is seen, although Malin's mother hopes her son to not be far away from her, for the mother live full of simplicity is enough as long as Malin, her only child remains by her side. Various attempts and persuasion had been made by the mother so Malin always close to her, but Malin's determination to wander could not be hindered by the mother. This determination was also seen when Malin conveyed his noble aspirations to make his mother happy, he said: "Later Malin must build a magnificent house for her and wear clothes that can amaze the eyes of many people".

Furthermore, the persistence value of the main character Malin is seen from the dialogue between Malin and Datuk. Malin said that he did not want to be called a coward. When Datuk said that going overseas not only with courage but also need provision or preparation so that overseas life could be passed well. Malin stated that he had provisions, namely "a will as hard as steel", this provision that he had would be able to face the various challenges and problems that would be when he wandered. This was revealed in Malin's conversation with Datuk, "I have to go through any waves, and no matter how fast the storms, I must go."

\subsubsection{Ethical Value}

Ethics is closely related to morality, which is a value system of how humans must maintain a good life which is manifested in a pattern of behavior that repeats itself over time and runs from time to time and becomes a habit. The Minangkabau Opera Malin Nan Kondang as a performance art emphasizes ethical values both in the script and in the performance. Textually, Malin Nan Kondang's Opera has a choice of words that are full of ethical values, such as the dialogue between Malin and Mandeh, in this dialogue, Malin in a young age has good morality, he politely expresses his wishes, even though Malin's mother was at the beginning disagree with Malin's wish to go wanderers, but Malin is still polite to his Mandeh.

Textually, Malin Nan Kondang's Opera has a choice of words that are full of ethical values, for example, in the dialogue between Malin and Mandeh, in this dialogue, Malin with a young age has good morality, he politely expresses his wishes, even though his Mandeh at the beginning, he did not agree with Malin's wish to go overseas, but Malin was still polite to his Mandeh. Malin always tries to convince Mandeh with good and beautiful language so that his heart is not offended, as in the following text, "Mandeh: I am happy enough if you are always close to me, my son... Malin: Award will not come by just standing hand? Later Malin must build a magnificent house and wear clothes that amaze the eye."

Ethical values can also be seen in Malin Nan Kondang Minangkabau Opera performance, where the supporters of the work, both actors, dancers, and musicians, show ethics in playing their respective roles, such as the way of dialogue between Malin and Mandeh, Malin and Datuk, Nilam and Malin's Mandeh. The dialogue act does not appear to violate the rules that apply to the Minangkabau customs, and teachings of Islamic Religion, Malin and Nilam always respect their parents in playing their respective roles and functions. There are also no dancers who violate the rules or norms that apply in society. Dancers, actors, and musicians also wear Minangkabau clothing and national clothes that reflect national culture without violating Islamic teachings. 


\subsubsection{Mutual Value}

The Minangkabau Opera Malin Nan Kondang is an artwork that combines theater, dance, and music. These three forms of performing arts are well packaged so that they become a work of art in the form of contemporary opera. In its implementation, this opera artwork certainly has shared values which can be seen in the training process where the director, scriptwriter, composer, and choreographer must be able to work together and reduce each other's egos in creating good work. Without togetherness, this work will not be created. Cooperation is also very visible in the training and performance process between actors, dancers, and musicians, these three components are very necessary to support and strengthen other components for the realization of a mutually agreed story.

The Minangkabau Opera Malin Nan Kondang is also determined by the strong togetherness between all the supporters of the work, namely, scriptwriters, directors, composers, choreographers, actors, musicians, and dancers. All of these components work together in the process of preparation, practice, and performance. The supporters of this work like one family and full of brotherly values, they work together in preparing the property, and other training needs and performance needs together.

\subsubsection{Aesthetic value}

Aesthetic value is a value based on beauty. Humans will feel peace and comfort in life. Human nature is predestined to like beautiful things. In Islamic concept, every human being has a beauty value such as how to speak, dress, act, and all behavior in life is regulated according to the aesthetic values that exist in Islam. Even Islam is the only religion that is most comprehensive in regulating and giving teachings in this field.

The Minangkabau Opera Malin Nan Kondang as a form of performance art has aesthetic values which can be seen in several aspects, including the artistic concept presented in the show, play acting, choreography, musical arrangement, and so on. On the artistic side, this work is designed as beautifully as possible by utilizing a stage backdrop by showing videos of Malin and Nilam as a child, pictures of rumah gadang, and photos of the natural beauty of West Sumatra. The backdrop is always presented with a good lighting arrangement so that the show is beautiful to watch. The artistic values that really stand out in this artwork are the lighting arrangements for each scene. Lighting gives strength to the story that is presented both to each character who performs the scene and to the dancer. The role of lighting in the Minangkabau Opera Malin Nan Kondang has two functions, namely as a support for the story through character scenes and as an artistic performance.

\section{CONCLUSION}

The Minangkabau Opera Malin Nan Kondang as a new form of art with a paradigm of transfer from Malin Kundang folklore is a work of art that has experienced several field tests at regional, national, and international levels. From the structural aspect, Malin Nan Kondang Opera consists of eight scenes with 48 minutes duration. The educational values contained in this work are: (1) the value of truth, (2) the value of persistence and perseverance, (3) ethical values, (4) the value of togetherness, and (5) aesthetic value. The truth value is illustrated in the dialogue section between Datuk and Malin, while the contents of the dialogue contain messages of truth. The value of persistence and perseverance is reflected in dialogue between Malin and Mandeh, Malin and Datuk, Malin and Nilam. Ethical values are clearly shown in texts/scripts and performances, where all supporters of the work have the same ethics, especially Malin and Nilam ethics as the main characters. Mutual value is reflected in the process of the work, the process of preparing for the show, and in the show itself, all supporters of the work together uphold togetherness. Furthermore, the aesthetic value is very visible on the packaging displayed at the time of the show which is also supported by the excellent lighting and sound system arrangement.

\section{ACKNOWLEDGMENTS}

The authors thank the Ministry of Research, Technology, and Higher Education, Republic of Indonesia, since part of this work is supported by DRPM DIKTI under 2019 Higher Education Excellence Consortium Research Program

\section{REFERENCES}

[1] Djamaris, E. 1984. Menggali Khazanah Sastra Melayu Klasik. Jakarta: Yayasan Asosiasi Tradisi Lisan.

[2] Koentjarningrat. 1990. Kebudayaan, Mentalitet, dan Pembangunan. Jakarta: Gramedia.

[3] Sabarani, Robert. 2012. Kearifan Lokal: Hakikat, Peran, dan Metode Tradisi Lisan. Jakarta: ATL.

[4] Abdurrahman dan Muhidin. 2011. Panduan Praktis Memahami Penelitian. Bandung: Pustaka Setia.

[5] Samovar, Larry, A dan E. Porter, Richard. 2010. Komunikasi Lintas Budaya: Communication Between Cultures. Jakarta: Salemba Humanika.

[6] Koentjaraningrat. 1993. Metode-metode Penelitian Masyarakat. Jakarta: Gramedia.

[7] Notoatmodjo, Soekidjo, 2003, Pengembangan Sumber Daya Manusia, Jakarta: PT. Rineka Cipta. 
[8] Nursid. 2011. Pendidikan Pemanusiaan Manusia Manusiawi. Bandung: Alfabeta

[9] Sjarkawi. 2011. Pembentukan Kepribadian Anak: Peran Moral, Intelektual, Emosional dan Sosial sebagai Wujud Integritas Membangun Jati Diri. Jakarta: Bumi Aksara.

[10] Bahardur, Iswadi. 2018. Local Wisdom of Minangkabau Culture in Traditional Performing Arts "Randai". Jentera: Jurnal Kajian Sastra Jentera, Desember 2018. Vol. 7 (2)

[11] Semi, Atar. 1993. Metode Penelitian Sastra. Bandung: Angkasa.

[12] Syuriadi, Helki dan Hasanuddin WS. 2014. "Nilai-nilai Pendidikan dalam Teks Cerita Randai "Malangga Sumpah" Karya Lukman Bustami Grup Randai Bintang Tampalo Kenagarian Padang Laweh Kabupaten Sijunjung". Jurnal Bahasa, Sastra dan Pembelajaran.

[13] Kutha Ratna, Nyoman. 2004. Teori, Metode, dan Teknik Penelitian Sastra. Yogyakarta: Pustaka Pelajar. 